\section{Population mobility, demographic, and environmental characteristics of dengue fever epidemics in a major city in Southeastern Brazil, 2007-2015}

\author{
Mobilidade populacional e características \\ demográficas e ambientais das epidemias de \\ dengue em uma metrópole no Sudeste do Brasil, \\ 2007-2015
}

\author{
Movilidad de la población y características \\ demográficas y ambientales de la epidemia \\ de dengue en una gran ciudad del sudeste \\ de Brasil, 2007-2015
}

Igor Cavallini Johansen 1 Marcia Caldas de Castro 2 Luciana Correia Alves 3 Roberto Luiz do Carmo ${ }^{3}$

doi: 10.1590/0102-311X00079620

\begin{abstract}
Around 14\% of world dengue virus (DENV) cases occur in the Americas, most of them in Brazil. While socioeconomic, environmental, and behavioral correlates have been analyzed thoroughly, the role played by population mobility on DENV epidemics, especially at the local level, remains scarce. This study assesses whether the daily pattern of population mobility is associated with DENV incidence in Campinas, a Brazilian major city with over 1.2 million inhabitants in São Paulo State. DENV notifications from 2007 to 2015 were geocoded at street level $(n=114,884)$ and combined with sociodemographic and environmental data from the 2010 population census. Population mobility was extracted from the Origin-Destination Survey (ODS), carried out in 2011, and daily precipitation was obtained from satellite imagery. Multivariate zero-inflated negative binomial regression models were applied. High population mobility presented a relevant positive effect on higher risk for $D E N V$ incidence. High income and residence in apartments were found to be protective characteristics against the disease, while unpaved streets, number of strategic points (such as scrapyards and tire repair shops), and precipitation were consistently risk factors.
\end{abstract}

Dengue; Population Dynamics; Environment
Correspondence

I. C. Johansen

Universidade de São Paulo.

Av. Professor Lineu Prestes 1374, sala 29, São Paulo, SP 05508-000, Brasil.

igorcavallini@usp.br

1 Universidade de São Paulo, São Paulo, Brasil.

${ }^{2}$ Harvard T.H. Chan School of Public Health, Harvard University, Boston, U.S.A.

3 Universidade Estadual de Campinas, Campinas, Brasil. 


\section{Introduction}

Despite the growing concern about other infectious diseases transmitted by Aedes aegypti, such as Zika virus and chikungunya, dengue virus (DENV) remains a global threat 1,2. The incidence of this disease has grown dramatically in recent decades. About 3.9 billion people in 128 countries are at risk of infection 3 . Regionally, approximately $70 \%$ of dengue cases are observed in Asia, followed by Africa (16\%) and the Americas, 14\% 4. In 2016, more than 3.1 million DENV cases were reported in the Americas, more than $70 \%$ of them in Brazil 5 .

Historically, Brazil succeeded in eliminating Ae. aegypti during the 1940s, and that campaign inspired the Pan American Health Organization (PAHO) to pursue the elimination in the Americas in the 1950s ${ }^{6}$. Although Ae. aegypti was eliminated from the Americas (with the exception of Colombia, Venezuela, British Guyana, Suriname, and the United States), the mosquito was reestablished in the early 1970s 7. The reintroduction of DENV in Brazil occurred at the beginning of the 1980s, at the Northern state of Amapá 8 . Since then, the disease has grown from an incidence rate close to 0 in 1985 to more than 735 cases per 100,000 inhabitants in 2019 9,10.

The urbanization process in Brazil produced cities founded on social inequalities, with profound differential access to sanitation services such as water provision as well as sewage system and garbage collection 11. These gaps in urban infrastructure made Brazilian cities highly suitable for the reproduction of Ae. aegypti 12,13,14,15, imposing a major obstacle to the implementation of DENV control policies. In parallel to human behavior 16 , incomplete urbanization is a key factor to understand the maintenance and expansion of the vector of this infectious disease in the country 17.

In Brazil's most populous state, São Paulo, DENV transmission began to be reported - with clinical and laboratory diagnosis - in March 1984 18. Campinas is the third most populous city in São Paulo, having first reported DENV autochthonous transmission in 1996 19. Since then the disease remained endemic, with major epidemics recorded in 2007, 2014, and 2015.

While socioeconomic, environmental, and behavioral correlates of dengue have been analyzed for different contexts in Brazil 20,21,22, more information is necessary to comprehend the role played by population mobility, especially at the local level. This study addresses this issue, and our hypothesis is that population movements are a relevant driving force for dengue diffusion locally. The analysis considered nine consecutive years (from 2007 to 2015), addressing temporal and spatial variations.

We chose Campinas because (i) dengue is an increasing public health threat in the city; (ii) in 2014, Campinas registered the highest number of DENV cases in the Brazil ( $7 \%$ of the total cases, while it shares only $0.6 \%$ of population in the country); (iii) in 2015 , the city recorded the most prominent DENV incidence rate among the municipalities with over 1 million inhabitants; (iv) it is highly diverse in socioeconomic status of population groups and in access to urban infrastructure (social inequalities), being similar to other Brazilian and Latin American urban contexts; and (v) Campinas has collected unique data on regular daily mobility.

\section{Methods}

\section{Study area}

The municipality of Campinas (22 $53^{\prime} 20^{\prime \prime} \mathrm{S}, 47^{\circ} 04^{\prime} 40^{\prime \prime} \mathrm{W}$ ) is located in Southeastern Brazil, the most economically dynamic region of the country. It has over 1.2 million inhabitants and it is located $100 \mathrm{~km}$ from the city of São Paulo, the capital of São Paulo State 23. Campinas is the geographical center and main city of the Campinas Metropolitan Area, composed of 20 municipalities, with 2.8 million inhabitants 24 . With an area of around $800 \mathrm{~km}^{2}$, the space occupation in Campinas municipality is highly heterogeneous. Although population density is about 1,360 people per $\mathrm{km}^{2}$, it considerably varies from highly populated to nearly empty neighborhoods. The weather is tropical, with rains during the summer (December to March), and drought in the winter (June to September). The average minimum temperature is $19^{\circ} \mathrm{C}\left(66.2^{\circ} \mathrm{F}\right)$, and the maximum is $29^{\circ} \mathrm{C}\left(84.2^{\circ} \mathrm{F}\right)$.

Despite its location within an economically developed area of the country, the city has patent contrasts in terms of population socioeconomic characteristics and urban infrastructure. There are 
still gaps in access to water, sewage, and garbage collection. Although the 2010 population census 23 reports that almost all the population had access to piped water (99\%), the regularity of the supply can vary according to the area of the city, a problem intensified during the severe drought the city faced in 2014, with subsequent water shortages 25 . Garbage and sewage collection are also virtually widespread, reaching $99 \%$ and $87 \%$ of the population, respectively 23 , although the remaining gaps are greater especially in the outskirts of the city.

The most affluent groups live in the center and north of the municipality, where urban infrastructure is of better quality. In contrast, the south concentrates the impoverished people, with less access to urban services. The urban configuration of Campinas encourages population mobility, given that the territory is abundantly crossed by major roads and highways (Figure 1).

\section{Figure 1}

Origin-Destination (OD) units of Campinas, São Paulo State, Brazil.

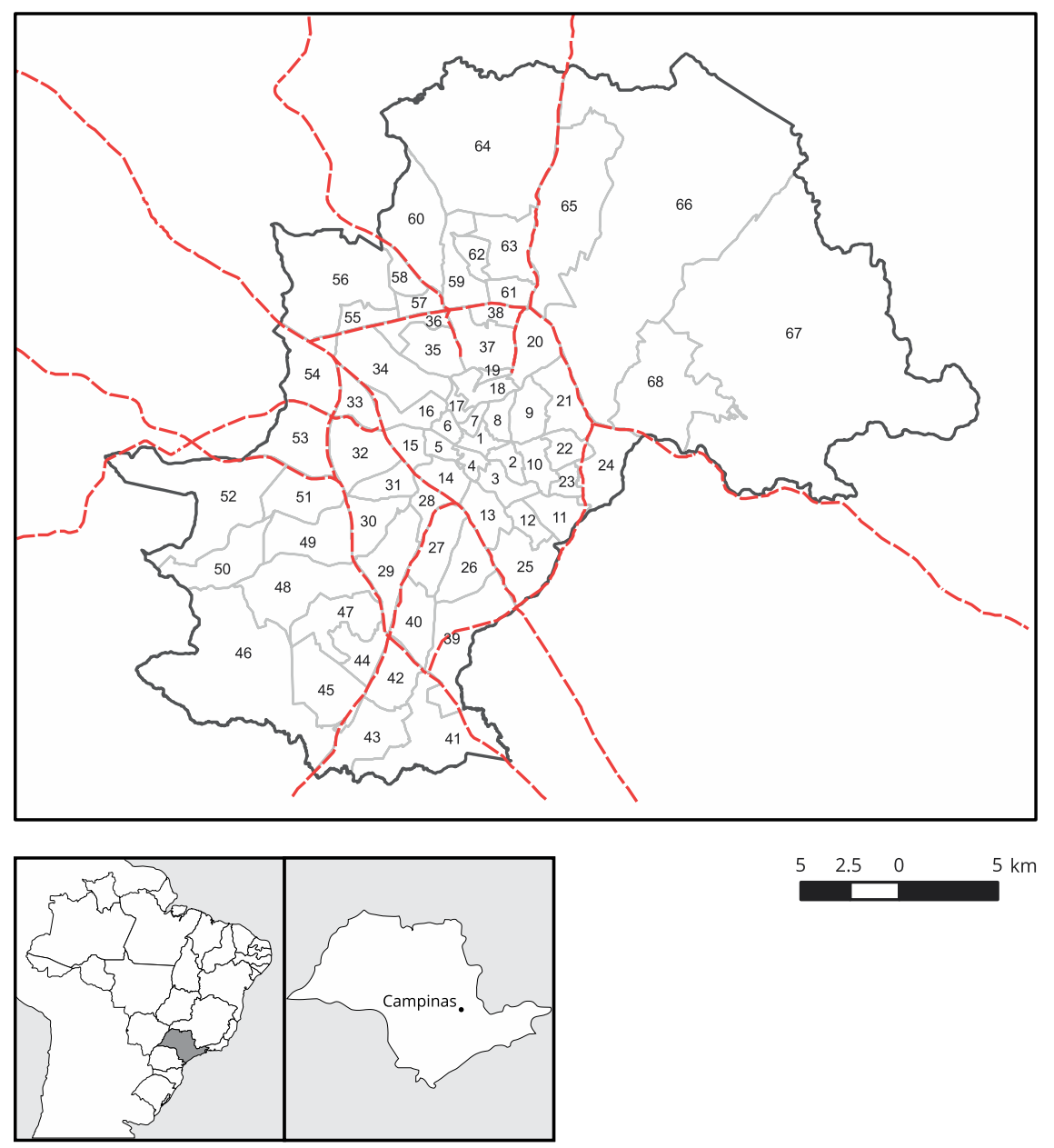

Source: elaborated by the authors based on the shapefiles from the Brazilian Institute of Geography and Statistics (IBGE), 2010, and State Metropolitan Transportation Secretariat, 2011.

Note: red dotted lines refer to the main state roads that cross Campinas; numbers refer to OD units; unit 1 (center of the figure) comprises the city center. 
Campinas had its first large dengue epidemic in 2007, with 1,100 cases per 100,000 inhabitants. Two consecutive epidemics followed in 2014, with 3,647 cases per 100,000 inhabitants, and in 2015, when over 5,600 cases per 100,000 inhabitants were registered. Each epidemic cycle corresponded to the circulation of a new serotype: DEN-3 in 2007 and DEN-1 in 2014 and 2015.

\section{Variables and data sources}

We studied 114,884 reported DENV autochthonous cases from January 1st 2007 to December 31st 2015, provided by the Information System on Diseases of Notification (SINAN) 26. The spatial location of the cases was recorded at the patients' household addresses. The transformation of addresses in coordinates was performed by an enterprise specialized at this task (Geograph Informática e Serviços Ltda., São Paulo, Brazil). Temporal detail was based on the reported date of the beginning of symptoms. Most cases were diagnosed using the clinical-epidemiological criteria, and a small number of cases were analyzed using serologic exams and virus isolation, which occurs especially for more severe cases and deaths.

To assess if high mobility was associated with high dengue incidence - while controlling for other correlates - we used information about population mobility in Campinas obtained from the Origin-Destination Survey (ODS), carried out in 2011 27. ODS included all population travels between or within ODS units (from now on called only OD units) during one regular business day (Monday to Friday); interviews were carried out from September to November 2011. The assumption in using these data was that patients infected with DENV are mobile.

ODS divided Campinas into 68 units, based on the transportation zoning system, urban equipment infrastructure, and physical barriers. In this study, we used 66 of these units (two of the 68 units were inhabited) as our main unit of analysis. The reasons for this choice were two-fold: (i) each OD unit comprised two or more census tracts, making it straightforward to merge mobility with census data; and (ii) households were sampled within each OD unit, impeding the reorganization of this information on other spatial units under the risk of biasing the survey results.

For each of the 66 OD units, we estimated dengue incidence rates (cases per 100,000 inhabitants) over the 469 epidemiological weeks of the study period. The epidemiological week is the main temporal unit that the Brazilian Ministry of Health uses to organize, to process, and to plan health policies in the country, including those concerning infectious diseases.

Furthermore, we calculated covariates that could influence DENV transmission. These covariates can broadly be categorized as demographic variables reflecting peoples' attributes (household per capita income, sex ratio, and population density), and environmental variables (residence in apartments, unpaved streets, and raw sewage). These variables were extracted from the 2010 population census 23 and aggregated to the OD unit level.

We also gathered data on strategic points (SP), comprising locations such as junkyards, tire repair shops, deposits of recyclable materials, etc. They are essential for understanding dengue occurrence, as these areas present huge potential to accumulate Aedes breeding sites 15,28,29. The addresses of SP in Campinas were obtained from the Superintendence for Control of Endemic Diseases (SUCEN) ${ }^{30}$, which allowed georeferencing and then obtaining the total number of SP per OD unit. Although the information on SP locations was available only for 2017, our assumption was that SP can change from one specific location to another, but their relative spatial distribution within Campinas tends to be similar over time.

Concerning environmental factors, we compiled data about rainfall, since water is essential for the vector reproduction. Weekly information on precipitation was extracted from the Climate Hazards Group InfraRed Precipitation with Station data 31. This dataset provides the estimated precipitation per day based on near real-time meteorological stations associated to satellite imagery, at a $5 \mathrm{~km}$ resolution. The accumulated precipitation was calculated per epidemiological week for each OD unit. After an assessment of previous works, we tested different lags: two weeks, four weeks (one month), eight weeks (two months), and 12 weeks (three months). This lag aimed to cover the expected time 
necessary for the precipitating water to pool, and for the entire cycle of transmission (from oviposition to a confirmed dengue case) to take place 10,21,32.

Three categorical variables were considered to better capture the intensity of transmission and mobility. The first, "high week", comprised weeks containing a proportion of dengue cases higher than $1.92 \%$ of total annual cases, which would be expected if cases were equally distributed along the weeks of the year $(0=$ no; $1=$ yes). The second, "high area", distinguished the ODs with more than 300 cases per 100,000 inhabitants, per week $(0=$ no; $1=$ yes). This threshold was chosen inspired by the Brazilian standard criteria to assess dengue incidence rates that are estimated annually 28; our study used the same criteria, but considering the week, in order to highlight the most prominent areas with high DENV figures. Finally, the variable "high mobility" identified areas with population mobility higher than the median observed in the city: 1,800 travels per 1,000 inhabitants $(0=$ no; $1=$ yes); this variable was calculated considering the differences in mobility levels between different ODs.

\section{Analytical approach}

A zero-inflated negative binomial regression (ZINB) model was used. The ZINB model accounts for extra-variation (overdispersion) in data 33. The outcome variable was dengue incidence rate: DENV cases per 100,000 inhabitants per OD unit and epidemiological week. Covariates included demographic (household income per capita, sex ratio, population density) and environmental factors (dwelling in apartments, unpaved streets, raw sewage, number of strategic points, and accumulated precipitation). Moreover, dummy variables were used for high mobility, high epidemiological weeks, and high incidence areas. The selection of independent variables to include in the final models was based on the stepwise backward process. The final model was chosen based on Akaike information criterion (AIC) for alternative distributions, such as negative binomial, Poisson, and zero-inflated.

Considering the variation of DENV distribution through space and time, five models were ran. Model 1 included all observations ( $\mathrm{n}=30,954$ OD-weeks). Models 2 and 3 were stratified by high ( $\mathrm{n}=8,778$ OD-weeks) and low epidemiological weeks ( $\mathrm{n}=22,176$ OD-weeks). Models 4 and 5 stratified the analysis by intensity of transmission, the former considering only high areas $(\mathrm{n}=637$ ODweeks) and the latter the low areas ( $\mathrm{n}=30,317$ OD-weeks). Models were controlled by year, taking 2015 as reference, accounting for differences between yearly variation in incidence rates. In all models, the variable population mobility was exactly the same, and statistical significance was evaluated at a $\mathrm{p}$-value $<0.01$.

Geographical information system (GIS) tools for merging different datasets were carried out in QGIS software version 3.10 (https://qgis.org/en/site/). Data cleaning, descriptive and statistical analyses were performed in Stata 14.0 (https://www.stata.com).

\section{Ethics statement}

This research does not require an Institutional Review Board approval because it comprises an analysis of secondary and anonymized data.

\section{Results}

From 2007 to 2015, 123,042 dengue cases were reported in Campinas, ranging from 159 in 2009 to 58,720 in 2015 . In total, 114,884 (93.4\%) cases did not present sufficient information to be geocoded at household level and included in the analysis. Geocoding success was high, and it varied from $90 \%$ in 2014 to $99.4 \%$ in 2009 . To validate the geocoding results, we investigated a randomly selected sample, comparing with their locations. We found an average error of $200 \mathrm{~m}$, what was acceptable considering that these points were afterwards aggregated into our analysis units.

Table 1 presents descriptive statistics of the continuous OD-level variables. DENV incidence rate per 100,000 inhabitants by OD-weeks, ranged from the mean 0.21 in 2009 to 96.92 in 2015. The smallest standard deviation was observed in 2009, 1.93, whereas the highest was 256.30, in 2015. After investigating different time lags: two, four, eight, and 12 weeks, we found that the eight-weeks 
Table 1

Descriptive statistics of the continuous Origin-Destination (OD)-level variables.

\begin{tabular}{|c|c|c|c|}
\hline Variables & Mean & SD & Range \\
\hline \multicolumn{4}{|l|}{ Reported dengue cases by OD-week (outcome) } \\
\hline \multicolumn{4}{|l|}{ Count (number of cases) } \\
\hline 2007 & 2.97 & 8.88 & $0-97$ \\
\hline 2008 & 0.77 & 0.33 & $0-6$ \\
\hline 2009 & 0.46 & 0.28 & $0-5$ \\
\hline 2010 & 0.61 & 2.16 & $0-43$ \\
\hline 2011 & 0.80 & 2.65 & $0-35$ \\
\hline 2012 & 0.15 & 0.60 & $0-11$ \\
\hline 2013 & 1.68 & 6.20 & $0-106$ \\
\hline 2014 & 10.74 & 33.91 & $0-481$ \\
\hline 2015 & 16.19 & 47.09 & $0-527$ \\
\hline \multicolumn{4}{|l|}{ Rate (cases per 100,000) } \\
\hline 2007 & 17.99 & 66.88 & $0.0-1,498.1$ \\
\hline 2008 & 0.60 & 7.80 & $0.0-3,74.5$ \\
\hline 2009 & 0.21 & 1.93 & $0.0-87.1$ \\
\hline 2010 & 3.79 & 16.58 & $0.0-374.5$ \\
\hline 2011 & 6.03 & 34.92 & $0.0-1,084.0$ \\
\hline 2012 & 0.91 & 8.20 & $0.0-374.5$ \\
\hline 2013 & 10.22 & 40.66 & $0.0-749.1$ \\
\hline 2014 & 63.22 & 164.66 & $0.0-2,264.8$ \\
\hline 2015 & 96.92 & 256.30 & $0.0-4,494.4$ \\
\hline \multicolumn{4}{|l|}{ Climate (exposure) } \\
\hline \multicolumn{4}{|l|}{ Precipitation lagged eight weeks (sum in $\mathrm{mm}$ ) } \\
\hline 2007 & 27.31 & 33.53 & $0.0-188.1$ \\
\hline 2008 & 28.86 & 26.32 & $0.0-137.5$ \\
\hline 2009 & 26.09 & 26.31 & $0.0-109.4$ \\
\hline 2010 & 30.19 & 37.78 & $0.0-163.8$ \\
\hline 2011 & 28.91 & 36.62 & $0.0-208.9$ \\
\hline 2012 & 32.32 & 33.68 & $0.0-172.5$ \\
\hline 2013 & 32.09 & 31.58 & $0.0-120.5$ \\
\hline 2014 & 24.90 & 25.87 & $0.0-124.1$ \\
\hline 2015 & 28.09 & 26.25 & $0.0-108.7$ \\
\hline \multicolumn{4}{|l|}{ Demographic (exposure) } \\
\hline Household income per capita (BRL) & $1,347.13$ & 850.18 & $397.4-4,031.8$ \\
\hline Total population sex ratio (male/female per 100 ) & 95.46 & 8.15 & $78.7-118.7$ \\
\hline Population density (persons/km²) & $3,260.38$ & $2,878.71$ & $15.1-13,180.3$ \\
\hline \multicolumn{4}{|l|}{ Environmental (exposure) } \\
\hline Number of SP & 9.8 & 13.6 & $0-65$ \\
\hline Residence in apartments (\%) & 18.94 & 22.46 & $0.0-95.0$ \\
\hline Households in unpaved streets (\%) & 7.21 & 11.34 & $0.0-59.8$ \\
\hline Households with open sewage (\%) & 3.82 & 8.1 & $0.0-38.4$ \\
\hline
\end{tabular}

SD: standard deviation; SP: strategic points.

Source: dengue - Information System on Diseases of Notification (SINAN); climate - Climate Hazards Group InfraRed Precipitation with Station data (CHIRPS); demographic (Household income per capita, Total population sex ratio, Population density) and environmental data (Residence in apartments, Households in unpaved streets, Households with open sewage) - population census, Brazilian Institute of Geography and Statistics (IBGE), 2010; Number of SP Superintendence for Control of Endemic Diseases (SUCEN). 
lag (two months) presented the highest coefficient associated with the dependent variable (dengue incidence rate). The sum of dengue cases and the accumulated precipitation lagged eight weeks is presented in Figure 2.

The accumulated precipitation (lagged by eight weeks) ranged from an average of $24.9 \mathrm{~mm}$ in 2014 to $32.3 \mathrm{~mm}$ in 2012. Mean household income per capita by OD was BRL 1,347.13, and the total population mean sex ratio among OD units was 95.46. Population density was, on average, 3,260 people per $\mathrm{km}^{2}$, although it considerably varied from the minimum 15 to the maximum 13,180. OD areas presented an average of $9.8 \mathrm{SP}$, ranging from 0 to 65 . Also, around $19 \%$ of all households were classified as apartment, these types of residence were most common in the downtown (up to $95 \%$ ). On average, $7.21 \%$ of households in the municipality were located in unpaved streets, varying substantially from one location to the other: from $0 \%$ in well-provided OD units to nearly $60 \%$ of unpaved streets in others. Also, an average of $3.82 \%$ households presented raw sewage, ranging from $0 \%$ to more than $38 \%$ across the different units of analysis.

Regarding the intensity of transmission and mobility (Table 2), there were 8,778 OD-weeks ( $28.4 \%$ of the total) with higher proportion of dengue cases than expected, while 637 OD-weeks were classified as High Areas (2.1\% of the total), i.e., with elevated incidence rates. Additionally, considering that the variable High Mobility uses the median to divide the OD areas in terms of population mobility, areas with high and low mobility are numerically identical, with 15,477 OD-weeks in each (50\%).

The spatial distribution of the total number of epidemiological weeks with high incidence rates shows a concentration of High Areas in the North of Campinas, encompassing neighborhoods such as Cidade Universitária, Real Parque, Jardim Santa Izabel, Parque das Universidades, Jardim São Marcos, and Jardim Santa Mônica. It also highlights the significance of DENV cases in the Southwest region, where we find Ouro Verde, Satélite Íris, Florence, Cosmos, Sirius, Jardim Paulicéia, and Jardim Campos Elísios neighborhoods. These areas are the ones with the highest historical concentration of dengue cases in the city during the study period, and it is also where epidemics recurrently occur.

As for the intensity of mobility, while the "most mobile" populations were apparently widespread in Campinas, they mostly overlapped with High Areas distribution, which beforehand suggested a link between population mobility and dengue occurrence. The exception to this pattern is the downtown, in which we notice high mobility but no expressive records of dengue occurrence.

\section{Figure 2}

Sum of dengue cases and accumulated precipitation (lagged eight weeks), by epidemiological weeks. Campinas, São Paulo State, Brazil, $2007-2015$.

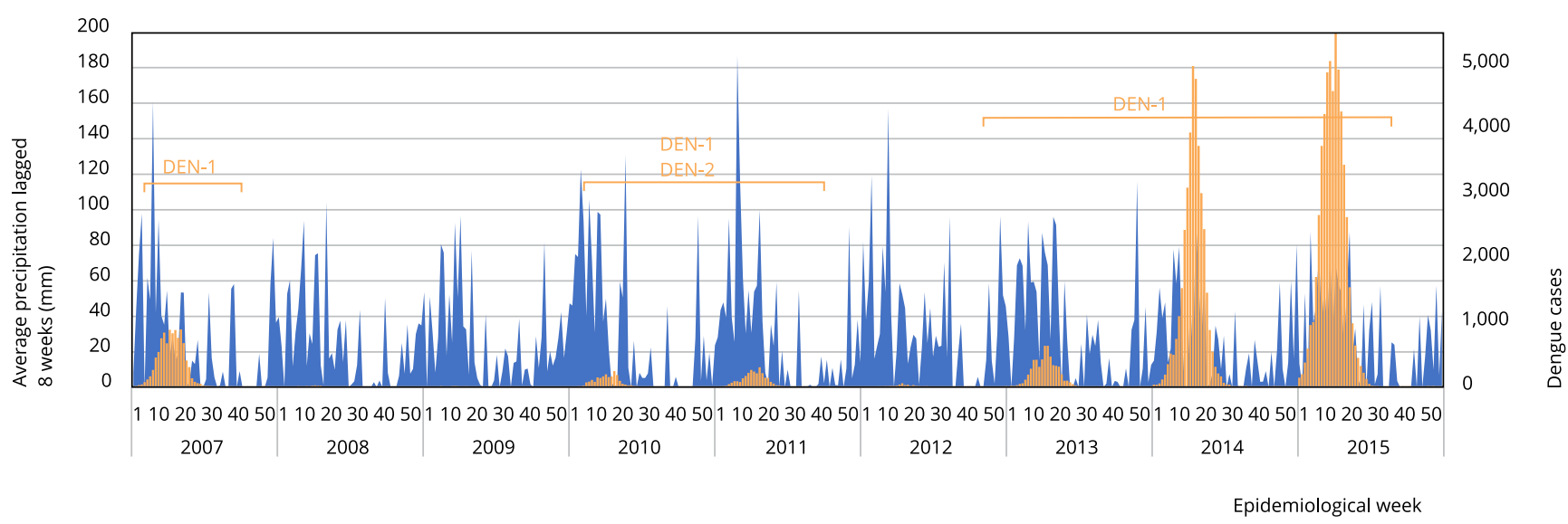

Source: dengue - Information System on Diseases of Notification (SINAN); climate - Climate Hazards Group InfraRed Precipitation with Station data (CHIRPS).

Note: dengue cases represented in orange bars and precipitation in blue area; predominant dengue serotype(s) indicated in orange. 
Table 2

Dummy variable definitions and descriptive statistics.

\begin{tabular}{llcc}
\hline Variables and description & Value & Observations (\%) & Total \\
\hline Scale (exposure) & & & \\
High week * & $0=$ No & $22,176(71.6)$ & 30,954 \\
High area ** & $0,778(28.4)$ & 30,954 \\
Mobility (exposure) & $1=$ No & $30,317(97.9)$ & \\
High mobility *** & & $637(2.1)$ & 30,954 \\
& $0=$ No & $15,477(50.0)$ & \\
\hline
\end{tabular}

Source: elaborated by the authors.

* Proportion of cases $>1.92 \%$ of the annual cases;

** > 300 cases per 100,000 inhabitants, by epidemiological week;

*** Population mobility $>1,800$ median travels per 1,000 inhabitants.

In assessing the role of population mobility, the complete model (Model 1, Table 3), showed that, on average, living in a highly mobile area was associated with an increase of $40 \%$ in dengue incidence rates. Over the entire study period, the increase of one SP in a study unit was followed by an increment, on average, of $3 \%$ in dengue incidence rates. Similarly, the increase of $1 \%$ in unpaved roads and raw sewage system was associated with an increase of $1 \%$ in dengue incidence rates. On the other hand, dwelling in apartments was protective against the disease, although barely significant. Indicator variables High Week and High Area were statistically significant and presented coefficients with high magnitude, supporting stratified analyses.

Table 1 also presents models stratified by high and low epidemiological weeks (Models 2 and 3), and by high and low incidence areas (Models 4 and 5). Results indicate that precipitation was positively associated with dengue incidence rates in periods of low transmission weeks and low incidence areas (Models 3 and 5). The variable households in unpaved streets was significantly correlated with dengue incidence rates in high transmission weeks and areas (Models 2 and 4). Living in high mobility areas was consistently a risk a factor for dengue incidence rates across all models. On average, living in a highly mobile area increased dengue incidence rate in $46 \%$ and $69 \%$ during high transmission weeks and in high transmission areas, respectively (Models 2 and 4). During low transmission weeks and in low transmission areas, highly mobile population increased by $26 \%$ and $35 \%$ dengue incidence rates, respectively (Models 3 and 5). Similarly to the complete model (Model 1), the mobility variable had the largest association with dengue incidence across all stratified models.

In Model 3, income per capita was protective against dengue fever, although not significant. Sex ratio was a protection factor against the disease in all stratified models, suggesting that more male residents are associated with a lower dengue incidence rate - in Models 2 and 4, the increase of one male per 100 female residents was followed by a decrease of $7 \%$ and $9 \%$ in the incidence rates, respectively.

Regarding SP, Models 1 to 5 showed that the addition of one SP contributed to an average increase of $3 \%$ in dengue incidence rates, with low variation across the different models. Similarly, the increase in $1 \%$ of population dwelling in apartments reduced approximately $1 \%$ to $2 \%$ of dengue incidence rates on average across the distinct models' stratification.

Population density did not differentiate residents across periods and areas with distinct levels of transmission (Models 1 to 5). Likewise, the increase in the proportion of households in each area with raw sewage system did not present substantial and consistent effects on dengue incidence rates.

Living in a high incidence area increased dengue rates by three times in high transmission weeks (Model 2), whereas in low transmission weeks it increased rates by eight times (Model 3). Conversely, during high transmission weeks living in high incidence areas duplicated dengue rates (Model 4), whereas living in low incidence areas increased dengue incidence by more than 15 times (Model 5). 
Table 3

Zero-inflated negative binomial regression (ZINB) models considering all Origin-Destination (OD)-weeks (Model 1), and stratified by High weeks (Model 2), Low weeks (Model 3), High areas (Model 4) and Low areas (Model 5).

\begin{tabular}{|c|c|c|c|c|c|c|c|c|c|c|}
\hline \multirow[t]{2}{*}{ Parameter } & \multicolumn{2}{|c|}{$\begin{array}{c}\text { Model } 1 \\
(n=30,954)\end{array}$} & \multicolumn{2}{|c|}{$\begin{array}{c}\text { Model } 2 \\
(n=8,778)\end{array}$} & \multicolumn{2}{|c|}{$\begin{array}{c}\text { Model } 3 \\
(n=22,176)\end{array}$} & \multicolumn{2}{|c|}{$\begin{array}{l}\text { Model } 4 \\
(n=637)\end{array}$} & \multicolumn{2}{|c|}{$\begin{array}{c}\text { Model } 5 \\
(n=30,317)\end{array}$} \\
\hline & IRR & $95 \% \mathrm{Cl}$ & IRR & $95 \% \mathrm{Cl}$ & IRR & $95 \% \mathrm{Cl}$ & IRR & $95 \% \mathrm{Cl}$ & IRR & $95 \% \mathrm{Cl}$ \\
\hline \multicolumn{11}{|l|}{ Climate } \\
\hline Precipitation & $1.01 *$ & $1.00-1.01$ & 0.99 & $0.99-1.00$ & $1.01 *$ & $1.01-1.02$ & 1.00 & $0.99-1.00$ & $1.01 *$ & $1.00-1.01$ \\
\hline \multicolumn{11}{|l|}{ Demographic } \\
\hline Income & 0.99 * & $0.99-0.99$ & 0.99 * & $0.99-0.99$ & 0.99 & $0.99-1.00$ & 0.99 * & $0.99-0.99$ & 0.99 * & $0.99-0.99$ \\
\hline Sex ratio & 0.94 * & $0.94-0.95$ & $0.93 *$ & $0.92-0.93$ & $0.98 * \star$ & $0.96-0.99$ & $0.91 *$ & $0.91-0.92$ & 0.96 * & $0.95-0.97$ \\
\hline Population density & $1.00 *$ & $1.00-1.00$ & $1.00 *$ & $1.00-1.00$ & 1.00 * & $1.00-1.00$ & 1.00 * & $1.00-1.00$ & $1.00 *$ & $1.00-1.00$ \\
\hline High mobility & $1.41 *$ & $1.32-1.49$ & 1.46 * & $1.38-1.55$ & 1.26 * & $1.12-1.42$ & 1.69 * & $1.52-1.88$ & 1.35 * & $1.26-1.44$ \\
\hline \multicolumn{11}{|l|}{ Environmental } \\
\hline SP & 1.03 * & $1.02-1.03$ & 1.03 * & $1.02-1.03$ & 1.03 * & $1.02-1.03$ & 1.02 * & $1.02-1.02$ & 1.03 * & $1.03-1.03$ \\
\hline Apartment & 0.98 * & $0.98-0.99$ & 0.98 * & $0.98-0.98$ & $0.99 *$ & $0.98-0.99$ & 0.99 * & $0.99-0.99$ & 0.98 * & 0.98-0.99 \\
\hline Unpaved & $1.01 *$ & $1.01-1.01$ & 1.02 * & $1.01-1.02$ & 0.99 & $0.99-1.01$ & 1.03 * & $1.03-1.04$ & 1.00 & $0.99-1.01$ \\
\hline Open sewage & $1.01 *$ & $1.01-1.02$ & $1.01 *$ & $1.00-1.01$ & 1.02 * & $1.00-1.03$ & 0.98 * & $0.97-0.99$ & $1.02 *$ & $1.01-1.02$ \\
\hline \multicolumn{11}{|l|}{ Scale } \\
\hline High week & 15.19 * & $14.32-16.11$ & & & & & 2.22 * & $1.72-2.88$ & 15.57 * & $14.62-16.58$ \\
\hline High area & $3.01 *$ & $2.67-3.41$ & 3.10 * & $2.85-3.38$ & 8.14 * & $3.57-18.56$ & & & & \\
\hline \multicolumn{11}{|l|}{ Year (reference: 2015) } \\
\hline 2007 & $0.21 *$ & $0.19-0.23$ & 0.29 * & $0.27-0.33$ & 0.16 * & $0.13-0.19$ & 0.29 * & $0.21-0.41$ & 0.20 * & $0.18-0.22$ \\
\hline 2008 & 0.01 * & $0.01-0.01$ & 0.01 * & $0.00-0.01$ & 0.01 * & $0.01-0.02$ & 0.12 & $0.01-1.07$ & 0.01 * & $0.00-0.01$ \\
\hline 2009 & 0.00 * & $0.00-0.00$ & 0.00 * & $0.00-0.00$ & 0.00 * & $0.00-0.01$ & 1.00 & - & 0.00 * & $0.00-0.00$ \\
\hline 2010 & 0.05 * & $0.04-0.05$ & 0.07 * & $0.06-0.07$ & 0.03 * & $0.02-0.04$ & 0.19 * & $0.06-0.61$ & 0.05 * & $0.04-0.05$ \\
\hline 2011 & 0.05 * & $0.05-0.06$ & 0.07 * & $0.06-0.08$ & 0.04 * & $0.03-0.05$ & 0.26 * & $0.16-0.45$ & 0.05 * & 0.04-0.05 \\
\hline 2012 & 0.01 * & $0.01-0.01$ & 0.01 * & $0.01-0.01$ & 0.02 * & $0.01-0.02$ & 0.12 & $0.01-1.13$ & 0.01 * & $0.01-0.01$ \\
\hline 2013 & $0.11 *$ & $0.10-0.12$ & 0.15 * & $0.14-0.17$ & 0.09 * & $0.08-0.18$ & 0.24 * & $0.17-0.35$ & 0.11 * & $0.09-0.19$ \\
\hline 2014 & 0.64 * & $0.59-0.69$ & 0.84 * & $0.77-0.91$ & 0.55 * & $0.48-0.63$ & 0.91 & $0.83-1.00$ & 0.62 * & $0.57-0.68$ \\
\hline
\end{tabular}

95\% Cl: 95\% confidence interval; IRR: incidence rate ratio; SP: strategic points.

Source: elaborated by the authors.

* $\mathrm{p} \leq 0.01$;

$\star \star p \leq 0.05$.

Consequently, living in high transmission areas was associated with a higher increase in dengue incidence rates during low transmission weeks. On the other hand, high transmission weeks were most positively associated with increases in dengue incidence rates in low incidence areas.

\section{Discussion}

This study investigates whether the daily pattern of population mobility associates with DENV transmission in Campinas. Our results showed that population mobility stood as a relevant correlate of dengue incidence, regardless of model specification.

While other studies have attempted to assess the role of population mobility, the geographical scale was often coarser 34,35,36,37,38. Our study advanced current knowledge by showing that, at the local level, it was in the high incidence rate areas and during high transmission weeks that population mobility exerted the most expressive influence on DENV transmission. These results were consistent across different model specification, and after controlling for sociodemographic and environmental 
variables. While population mobility was a pertinent factor for the occurrence of DENV epidemics, we found that high mobility and high dengue incidence rates did not perfectly overlap. For example, residents in the downtown are highly mobile, but the area was not associated with high DENV transmission. Based on our results, the type of household could be a possible explanation, as most downtown inhabitants live in apartments, often considered a protective factor against the DENV vector 39,40,41. Dwelling in apartments was also a variable correlated with income in Campinas, as verticalization occurs more expressively in the downtown, which is also the region with the highest concentration of more affluent people. This result corroborates previous findings of the role of income in DENV epidemics 15,22,42.

The high concentration of population mobility in downtown is mainly due to: (1) concentration of jobs and (2) the way public transportation is organized. However, the data used in our study go beyond this general pattern. This occurs because all trips, for all reasons (study, work, leisure, etc.) and using every type of transportation (bus, car, motorcycle, etc.) was addressed. Furthermore, a new trip is registered each time a person stops in a study unit area, so the entire trajectory in the city is considered in our analysis. Therefore, this investigation handled detailed mobility of the population, being able to accurately capture all places where individuals passed by and, consequently, where they could be infected or facilitated the virus dissemination.

Although dengue seems to spread throughout the city, it is more prevalent in areas with precarious socio-environmental conditions, corroborating previous studies 13,19,43. We found that DENV cases were more concentrated in - although not limited to - the Southern, Southwestern, and Northwestern portions of Campinas. These are notable areas that concentrate less affluent populations and where environmental conditions favor the occurrence of Aedes breeding sites, highlighting the role of local inequalities in transmission. Unpaved streets and raw sewage system, proxies of local environmental quality, were significant risk factors for DENV in the high weeks and high areas transmission models (Models 2 and 4), corroborating previous findings 12,17,20,43,44,45,46,47. Regarding population density - although previous analysis has found a positive association with dengue incidence 48,49 our results found no association, as high population density occurs also in downtown, where apartment buildings, a protective factor, predominate.

Precipitation (using an 8-week time lag) was a risk factor for DENV particularly during low weeks (May to January approximately) and low areas transmission models (Models 3 and 5, respectively). It is noteworthy that the most common types of breeding habitats in Campinas are recipients such as plant vases, animal drinkers, demountable swimming pools, cans, bottles and buckets, etc. 30 . Abundance of these containers are directly a result of human behavior and do not necessarily depend on rainwater to be filled up. Moreover, the effect of precipitation can happen in an indirect way. For example, the 2014 epidemics occurred during a severe drought in Campinas 25, which resulted in a behavior of storing water in barrels at home, not always properly covered, then favoring the proliferation of breeding habitats.

There is still an open debate about the role played by sex ratio on dengue epidemics 50 . We found that, on average, men have fewer infections, particularly in high transmission weeks and areas (Models 2 and 4). Nevertheless, these results should be analyzed with caution. There is evidence that women usually seek health care assistance more frequently, not necessarily meaning that they are more affected by diseases, but, instead, that they tend to be more careful with their own wellness 51,52. In Brazil, a previous study found higher dengue notification among women 53,54, while other showed no significant sex difference 55,56. In our data, from 2007 to 2015, 55\% of patients that notified DENV cases were women while $45 \%$ were men, while the 2010 population census indicates that $52 \%$ of the residents in Campinas were women, and $48 \%$ were men 23 . This sex difference is significant because there is a distinct mobility pattern between males and females. The ODS showed that women tended to have higher mobility within their area of residence, and therefore travel smaller distances than men. The extent to which this pattern implies lower exposure to an infection depends on the characteristics of the areas where they live and where they usually go.

Regarding SPs, we found that the addition of one SP in an area tended to increase dengue incidence rate by $3 \%$, a result consistent with previous findings 15,29. Although there are clear guidelines on how to monitor SP, including mandatory inspection visits every 15 days 28, limited financial resources, skilled professionals, or even violence in an area can affect the regularity of these visits 13,15 . 
This study has some limitations. Firstly, the spatial unit of analysis used was not the finest possible. However, considering that the ODS was conducted based on a sample of the population of each area, the spatial units could not be downsampled. Secondly, the flow of people traveling by air and by bus to other municipalities outside the Metropolitan Area was not addressed in this analysis. Yet, these travels represent a minor part in total daily travel, and thus are unlikely to change our results. Thirdly, as it is the case for any administrative record on DENV infections, they capture only symptomatic cases (those that are registered by the health facility); that is a limitation for any DENV study that relies on administrative records. Fourthly, although reporting of DENV is mandatory, some private facilities do not fully report the occurrence of cases. Nevertheless, the private sector represents a minority of cases, unlikely to bias the results. Fifthly, this study did not contemplate directions of population mobility in a more detailed time frame, restricting the concomitant analysis with the variation of DENV in space and time. Finally, considering data restrictions, we could not precisely assess the mobility pattern of DENV infected patients. Our results indirectly assess how this variable correlate with DENV occurrence, implying association instead of causality.

In this study, we analyzed a large and unique data that combined DENV cases geocoded to patient's residence addresses, socioeconomic characteristics, and mobility information, in a detailed timeframe, for nine consecutive years. Our results provided insights about DENV determinants in a large urban center, suggesting patterns that could be similar in other large cities in Brazil, and also in Latin America.

\section{Contributors}

I. C. Johansen contributed to the study conception and design, data curation, formal analysis, methodology, and writing. M. C. Castro contributed to the formal analysis, methodology, and writing. L. C. Alves and R. L. Carmo contributed to the study conception and design and methodology. All authors approved the final version of the article.

\section{Additional informations}

ORCID: Igor Cavallini Johansen (0000-0002-53603740); Marcia Caldas de Castro (0000-0003-46062795); Luciana Correia Alves (0000-0002-85984875); Roberto Luiz do Carmo (0000-0003-10632266).

\section{Acknowledgments}

We thank the Campinas Municipal Health Secretariat for providing part of the data used in this study. This study was funded by the Brazilian National Research Council (CNPq) as a PhD scholarship for the Graduate Program in Demography at University of Campinas (Unicamp). The Brazilian Graduate Studies Coordinating Board (CAPES) provided additional resources for a "Sandwich Program" at Harvard T.H. Chan School of Public Health, United States (process n. 88881.132765/2016-01). The funders had no role in study design, data collection and analysis, decision to publish, or preparation of the manuscript. 


\section{References}

1. Gubler DJ, Ooi EE, Vasudevan S, Farrar J. Dengue and dengue hemorrhagic fever. Wallingford: CABI; 2014.

2. Hotez PJ. Neglected tropical diseases in the Anthropocene: the cases of Zika, Ebola, and other infections. PLoS Negl Trop Dis 2016; 10:e0004648.

3. Brady OJ, Gething PW, Bhatt S, Messina JP, Brownstein JS, Hoen AG, et al. Refining the global spatial limits of dengue virus transmission by evidence-based consensus. PLoS Negl Trop Dis 2012; 6:e1760.

4. Bhatt S, Gething PW, Brady OJ, Messina JP, Farlow AW, Moyes CL, et al. The global distribution and burden of dengue. Nature 2013; 496:504-7.

5. Pan American Health Organization. Reported cases of dengue fever in the Americas. https:// www.paho.org/data/index.php/en/mnu-top ics/indicadores-dengue-en/dengue-nacionalen/252-dengue-pais-ano-en.html (accessed on $15 / \mathrm{Jan} / 2020$ ).

6. Soper FL. The elimination of urban yellow fever in the Americas through the eradication of Aedes aegypti. Am J Public Health Nations Health 1963; 53:7-16.

7. Kotsakiozi P, Gloria-Soria A, Caccone A, Evans B, Schama R, Martins AJ, et al. Tracking the return of Aedes aegypti to Brazil, the major vector of the dengue, chikungunya and Zika viruses. PLoS Negl Trop Dis 2017; 11:e0005653.

8. Osanai CH, Travassos da Rosa APA, Tang AT, Amaral RS, Passos ADC, Tauil PL. Surto de dengue em Boa Vista, Roraima. Nota prévia. Rev Inst Med Trop São Paulo 1983; 25:53-4.

9. Ministério da Saúde. Monitoramento dos casos de arboviroses urbanas transmitidas pelo Aedes aegypti (dengue, chikungunya e zika), semanas epidemiológicas 1 a 50, 2020. Boletim Epidemiológico 2020; 51(51):1-15.

10. de Azevedo TS, Lorenz C, Chiaravalloti-Neto F. Spatiotemporal evolution of dengue outbreaks in Brazil. Trans R Soc Trop Med Hyg 2020; 114:593-602.

11. Cano W. Ensaios sobre a crise urbana do Brasil. Campinas: Editora da Unicamp; 2011.

12. Johansen IC, Luiz do Carmo R, do Carmo D, Bueno M. Water, sanitation and health: an intra-urban comparison in the municipality of Caraguatatuba, Brazil. Water Int 2013; 38:888901.

13. Johansen IC, Carmo RL, Alves LC. Desigualdade social intraurbana: implicações sobre a epidemia de dengue em Campinas, SP, em 2014. Cadernos Metrópole 2016; 18:421-40.

14. Pasternak S. Habitação e saúde. Estud Av 2016; 30:51-66.

15. MacCormack-Gelles B, Wilson ME, Castro MC, Lima Neto AS, Sousa GS, Nascimento OJ, et al. Epidemiological characteristics and determinants of dengue transmission during epidemic and non-epidemic years in Fortaleza, Brazil: 2011-2015. PLoS Negl Trop Dis 2018; 12:e0006990.
16. Souza KR, Santos MLR, Guimarães ICS, Ribeiro GDS, Silva LK. Saberes e práticas sobre controle do Aedes aegypti por diferentes sujeitos sociais na cidade de Salvador, Bahia, Brasil. Cad Saúde Pública 2018; 34:e00078017.

17. Queiroz JTM, Silva PN, Heller L. New premises for sanitation in arbovirus infections control in Brazil. Cad Saúde Pública 2020; 36:e00223719.

18. Rocco IM, Ferreira IB, Katz G, Souza LTM, Souza DM, Kimura-Gushiken EK, et al. Ocorrência de dengue no Estado de São Paulo, Brasil, de 1986 a 1996. Rev Inst Adolfo Lutz 1998; 57:7-12.

19. Malavasi HG. Análise espacial da epidemia de dengue em Campinas/SP no ano de 2007 [Dissertação de Mestrado]. Campinas: Universidade Estadual de Campinas; 2011.

20. Teixeira MG, Siqueira Jr. JB, Ferreira GLC, Bricks L, Joint G. Epidemiological trends of dengue disease in Brazil (2000-2010): a systematic literature search and analysis. PLoS Negl Trop Dis 2013; 7:e2520.

21. Colón-González FJ, Fezzi C, Lake IR, Hunter PR. The effects of weather and climate change on dengue. PLoS Negl Trop Dis 2013; 7:e2503.

22. Bavia L, Melanda FN, de Arruda TB, Mosimann ALP, Silveira GF, Aoki MN, et al. Epidemiological study on dengue in southern Brazil under the perspective of climate and poverty. Sci Rep 2020; 10:2127.

23. Instituto Brasileiro de Geografia e Estatística. Censo Demográfico 2010. Rio de Janeiro: Instituto Brasileiro de Geografia e Estatística; 2011.

24. Cunha JMP, Falcão CA. Campinas metropolitana: diversidades socioespaciais na virada para o século XXI. Campinas: Librum Editora; 2017.

25. Anazawa TM. A grave escassez hídrica e as dimensões de um desastre socialmente construído: a Região Metropolitana de Campinas entre 2013-2015 [Tese de Doutorado]. Campinas: Universidade Estadual de Campinas; 2017.

26. Ministério da Saúde. Dengue cases in Campinas 2007-2015. Brasília: Ministério da Saúde; 2018.

27. Secretaria de Estado dos Transportes Metropolitanos. Pesquisa origem e destino domiciliar da Região Metropolitana de Campinas: síntese dos resultados. São Paulo: Secretaria de Estado dos Transportes Metropolitanos; 2011.

28. Ministério da Saúde. Diretrizes nacionais para a prevenção e controle de epidemias de dengue. Brasília: Ministério da Saúde; 2009.

29. Johansen IC, Do Carmo RL, Alves LC, Dias Bueno MDC. Environmental and demographic determinants of dengue incidence in Brazil. Rev Salud Pública 2018; 20:346-51.

30. Superintendência de Controle de Endemias. Levantamento Rápido de Índices para Aedes aegypti (LIRAa) em Campinas entre 2011 e 2015. http://200.144.1.21/cdengue/ (accessed in $10 / \mathrm{Feb} / 2020)$. 
31. Funk C, Peterson P, Landsfeld M, Pedreros D, Verdin J, Shukla S, et al. The climate hazards infrared precipitation with stations: a new environmental record for monitoring extremes. Sci Data 2015; 2:150066.

32. Atique S, Abdul SS, Hsu C-Y, Chuang T-W. Meteorological influences on dengue transmission in Pakistan. Asian Pac J Trop Med 2016; 9:954-61.

33. Gschlößl S, Czado C. Modelling count data with overdispersion and spatial effects. Statistical Papers 2008; 49:531.

34. Kraemer MUG, Perkins TA, Cummings DAT, Zakar R, Hay SI, Smith DL, et al. Big city, small world: density, contact rates, and transmission of dengue across Pakistan. J R Soc Interface 2015; 12:20150468.

35. Telle O, Vaguet A, Yadav NK, Lefebvre B, Daudé E, Paul RE, et al. The spread of dengue in an endemic urban milieu: the case of Delhi, India. PLoS One 2016; 11:e0146539.

36. Tian H, Sun Z, Faria NR, Yang J, Cazelles B, Huang $S$, et al. Increasing airline travel may facilitate co-circulation of multiple dengue virus serotypes in Asia. PLoS Negl Trop Dis 2017; 11:e0005694.

37. Gardner LM, Bóta A, Gangavarapu K, Kraemer MUG, Grubaugh ND. Inferring the risk factors behind the geographical spread and transmission of Zika in the Americas. PLoS Negl Trop Dis 2018; 12:e0006194.

38. Salami D, Capinha C, Martins MRO, Sousa CA. Dengue importation into Europe: a network connectivity-based approach. PLoS One 2020; 15:e0230274.

39. Zellweger RM, Cano J, Mangeas M, Taglioni F, Mercier A, Despinoy M, et al. Socioeconomic and environmental determinants of dengue transmission in an urban setting: an ecological study in Nouméa, New Caledonia. PLoS Negl Trop Dis 2017; 11:e0005471.

40. Aik J, Neo ZW, Rajarethinam J, Chio K, Lam WM, Ng L-C. The effectiveness of inspections on reported mosquito larval habitats in households: a case-control study. PLoS Negl Trop Dis 2019; 13:e0007492.

41. Luna EJA, Figueiredo GM, Levi JE, Campos SRSLC, Felix AC, Souza NS, et al. A cohort study to assess the incidence of dengue, Brazil, 2014-2018. Acta Trop 2020; 204:105313.

42. Xavier DR, Magalhães MAFM, Gracie R, Reis IC, Matos VP, Barcellos C. Difusão espaçotempo do dengue no Município do Rio de Janeiro, Brasil, no período de 2000-2013. Cad Saúde Pública 2017; 33:e00186615.

43. Cordeiro R, Donalisio MR, Andrade VR, Mafra ACN, Nucci LB, Brown JC, et al. Spatial distribution of the risk of dengue fever in southeast Brazil, 2006-2007. BMC Public Health 2011; 11:355.

44. Almeida AS, Medronho RDA, Valencia LIO. Análise espacial da dengue e o contexto socioeconômico no município do Rio de Janeiro, RJ. Rev Saúde Pública 2009; 43:666-73.
45. Braga C, Luna CF, Martelli CM, De Souza WV, Cordeiro MT, Alexander N, et al. Seroprevalence and risk factors for dengue infection in socio-economically distinct areas of Recife, Brazil. Acta Trop 2010; 113:234-40.

46. Lana RM, Carneiro TGS, Honório NA, Codeço CT. Seasonal and nonseasonal dynamics of Aedes aegypti in Rio de Janeiro, Brazil: fitting mathematical models to trap data. Acta Trop 2014; 129:25-32.

47. Kikuti M, Cunha GM, Paploski IAD, Kasper AM, Silva MMO, Tavares AS, et al. Spatial distribution of dengue in a Brazilian urban slum setting: role of socioeconomic gradient in disease risk. PLoS Negl Trop Dis 2015; 9:e0003937.

48. de Moura Rodrigues M, Marques GRAM, Serpa LLN, de Brito Arduino M, Voltolini JC, Barbosa GL, et al. Density of Aedes aegypti and Aedes albopictus and its association with number of residents and meteorological variables in the home environment of dengue endemic area, São Paulo, Brazil. Parasit Vectors 2015; $8: 115$.

49. Barrera R, Delgado N, Jiménez M, Villalobos I, Romero I. Estratificación de una ciudad hiperendémica en dengue hemorrágico. Rev Panam Salud Pública 2000; 8:225-33.

50. L'Azou M, Taurel A-F, Flamand C, Quenel P. Recent epidemiological trends of dengue in the French territories of the Americas (20002012): a systematic literature review. PLoS Negl Trop Dis 2014; 8:e3235.

51. Mendoza-Sassi RA, Béria JU. Gender differences in self-reported morbidity: evidence from a population-based study in southern Brazil. Cad Saúde Pública 2007; 23:341-6.

52. Thompson AE, Anisimowicz Y, Miedema B, Hogg W, Wodchis WP, Aubrey-Bassler K. The influence of gender and other patient characteristics on health care-seeking behaviour: a QUALICOPC study. BMC Fam Pract 2016; 17:38.

53. Cardoso IM, Cabidelle ASA, Lang CF, Calenti FG, Nogueira LO, Falqueto A, et al. Dengue: clinical forms and risk groups in a high incidence city in the southeastern region of Brazil. Rev Soc Bras Med Trop 2011; 44:430-5.

54. Cavalcanti LPG, Coelho ICB, Vilar DCLF, Holanda SGS, Escóssia KNF, Souza-Santos R. Clinical and epidemiological characterization of dengue hemorrhagic fever cases in northeastern, Brazil. Rev Soc Bras Med Trop 2010; 43:355-8.

55. Hino P, Santos CC, Santos MO, Cunha TN, Santos CB. Evolução temporal da dengue no município de Ribeirão Preto, São Paulo, 1994 a 2003. Ciênc Saúde Colet 2010; 15:233-8.

56. Nunes PCG, Daumas RP, Sánchez-Arcila JC, Nogueira RMR, Horta MAP, dos Santos FB. 30 years of fatal dengue cases in Brazil: a review. BMC Public Health 2019; 19:329. 


\section{Resumo}

Cerca de $14 \%$ de todos os casos de dengue (DENV) ocorrem nas Américas, a maioria dos quais no Brasil. Os correlatos socioeconômicos, ambientais e comportamentais já foram analisados em profundidade, mas há pouco conhecimento, principalmente em nivel local, sobre o papel da mobilidade populacional nas epidemias de DENV. O estudo pretende verificar se o padrão diário de mobilidade populacional está associado à incidência do DENV em Campinas, cidade brasileira com mais de 1,2 milhão de habitantes no Estado de São Paulo. As notificações de DENV entre 2007 e 2015 foram georreferenciadas em nivel de logradouro $(n=114.884)$ e combinadas com dados sociodemográficos e ambientais do censo populacional de 2010. A mobilidade populacional foi extraida da Pesquisa de Origem/Destino (POD) realizada em 2011, e a pluviometria diária foi obtida através de imagens de satélite. Foram aplicados modelos de regressão multivariada com resposta binomial negativa inflacionados de zeros. A mobilidade populacional alta apresentou efeito positivo relevante sobre a incidência mais elevada de DENV. Renda alta e residência em apartamento mostrou efeito protetor contra a doença, enquanto ruas não pavimentadas, número de pontos críticos (p.ex.: ferros-velhos e borracharias) e pluviosidade alta apareceram enquanto fatores de risco.

Dengue; Dinâmica Populacional; Meio Ambiente

\section{Resumen}

Alrededor del $14 \%$ de los casos mundiales de virus dengue (DENV por sus siglas en inglés) se produce en las Américas, la mayoría de ellos en Brasil. Mientras que las correlaciones socioeconómicas, ambientales y de comportamiento se han analizado a fondo, el papel jugado por la movilidad de la población con epidemia de DENV, especialmente en un nivel local, continúa siendo escasa. Este estudio evalúa si el patrón diario de movilidad de población está asociado con la incidencia de DENV en Campinas, una gran ciudad brasileña con más de 1,2 millones de habitantes en el estado de São Paulo. Las notificaciones de DENV desde 2007 a 2015 fueron geocodificadas en un nivel de calle $(n=114,884)$, y combinadas con datos sociodemográficos, además de ambientales mediante el censo de población de 2010. La movilidad de la población se extrajo de la Encuesta Origen-Destino (ODS por sus siglas en inglés), llevada a cabo en 2011, la precipitación diaria se obtuvo mediante imágenes por satélite. Se aplicaron modelos de regresión binomial negativa multivariados con ceros inflados. La alta movilidad de la población presentó un efecto positivo relevante, respecto a un mayor riesgo en la incidencia por DENV. Contar con ingresos altos y residir en apartamentos resultaron ser factores protectores contra la enfermedad, mientras que las calles sin pavimentar, así como algunos puntos estratégicos como los desguaces $y$ tiendas de reparación de ruedas, al igual que las precipitaciones fueron consistentemente factores de riesgo.

Dengue; Dinámica Poblacional; Ambiente
Submitted on 12/Apr/2020

Final version resubmitted on $03 / \mathrm{Jul} / 2020$

Approved on 31/Jul/2020 